Article

\title{
Chemical Composition of Four Essential Oils of Eugenia from the Brazilian Amazon and Their Cytotoxic and Antioxidant Activity
}

\author{
Joyce Kelly R. da Silva ${ }^{1,2}$, Eloisa Helena A. Andrade ${ }^{2,3}$, Leilane H. Barreto ${ }^{4}$, \\ Nádia Carolina F. da Silva ${ }^{4}$, Alcy F. Ribeiro ${ }^{2}$, Raquel C. Montenegro ${ }^{1,4}$ and \\ José Guilherme S. Maia ${ }^{2,5, *}$ \\ 1 Programa de Pós-Graduação em Biotecnologia, Universidade Federal do Pará, Belém 66075-110, Brazil; \\ joycekellys@ufpa.br (J.K.R.d.S.); rcm.montenegro@gmail.com (R.C.M.); \\ 2 Programa de Pós-Graduação em Química, Universidade Federal do Pará, Belém 66075-110, Brazil; \\ eloisandrade@ufpa.br (E.H.A.A.); favacho@ufpa.br (A.F.R.) \\ 3 Coordenação de Botânica, Museu Paraense Emilio Goeldi, Belém 66077-530, Brazil \\ 4 Laboratório de Citogenética Humana, Universidade Federal do Pará, Belém 66075-900, Brazil; \\ leilanebarreto@yahoo.com.br (L.H.B.); nadia_fonseca_silva@hotmail.com (N.C.F.d.S.) \\ 5 Programa de Pós-Graduação em Recursos Naturais da Amazônia, Universidade Federal do Oeste do Pará, \\ Santarém 68035-110, Brazil \\ * Correspondence: gmaia@ufpa.br; Tel.: +55-91-981467067
}

Academic Editors: Eleni Skaltsa and Gerhard Litscher

Received: 21 June 2017; Accepted: 5 July 2017; Published: 8 July 2017

\begin{abstract}
Background: Eugenia species are appreciated for their edible fruits and are known as having anticonvulsant, antimicrobial and insecticidal actions. Methods: The plant material was collected in the southeastern Pará state of Brazil and submitted to hydrodistillation. GC-MS analyzed the oils, and their antioxidant and cytotoxic activities were evaluated by the DPPH and MTT assays. Results: The main components identified in the Eugenia oils were 5-hydroxy-cis-calemene, $(2 E, 6 E)$-farnesol, (2E,6Z)-farnesol, caryophylla-4(12),8(13)-dien- $5 \alpha$-ol-5 $\beta$-ol, $E-\gamma$-bisabolene, $\beta$-bisabolene, germacrene $\mathrm{D}$, and ishwarane. The oil of E. egensis showed the most significant antioxidant activity $(216.5 \pm 11.6 \mathrm{mg} \mathrm{TE} / \mathrm{mL})$, followed by the oils of E. flavescens $(122.6 \pm 6.8 \mathrm{mg} \mathrm{TE} / \mathrm{mL})$ and E. patrisii (111.2 $\pm 12.4 \mathrm{mg}$ TE/mL). Eugenia oils were cytotoxic to HCT-116 (colon cancer) cells by the MTT assay, where the most active was the oil of E. polystachya $(10.3 \mu \mathrm{g} / \mathrm{mL})$, followed by the oils of E. flavescens $(13.9 \mu \mathrm{g} / \mathrm{mL})$ and E. patrisii $(16.4 \mu \mathrm{g} / \mathrm{mL})$. The oils of E. flavescens and E. patrisii showed the highest toxicity for MRC5 (human fibroblast) cells, with values of $14.0 \mu \mathrm{g} / \mathrm{mL}$ and $18.1 \mu \mathrm{g} / \mathrm{mL}$, respectively. Conclusions: These results suggest that Eugenia oils could be tested in future studies for the treatment of colon cancer and oxidative stress management.
\end{abstract}

Keywords: Eugenia egensis; E. flavescens; E. patrisii; E. polystachya; Myrtaceae; essential oil; cytotoxicity; antioxidant activity

\section{Introduction}

Myrtaceae Juss. comprises 142 genera and about 5500 species of trees and shrubs, distributed in the tropical and subtropical regions of the world, with centers of diversity in Tropical America and Oceania, and a few species in Africa [1]. In Brazil, it is one of the most diverse and is mainly represented by fruit trees. Twenty-three genera and about 1000 species were found and all belonged to the Myrtoideae subfamily and Myrteae tribe [2,3]. Eugenia L. is one of the largest genera within Myrtaceae and 388 species are native in Brazil [3]. Eugenia egensis DC., common name "cambuí" (syn. E. egensis var. grandifolia O. Berg, E. erythrocarpa Barb. Rodr., E. parodiana Morong, E. perforata O. 
Berg, E. pothaplosantha Barb. Rodr., E. sphaerosperma DC., E. tenuiramis Miq.), Eugenia flavescens DC., common name araçá-da-mata" (syn. E. flavescens var. guianensis Sagot), Eugenia patrisii Vahl, known as "ubaia-rubí" (syn. E. berlynensis O. Berg, E. inocarpa DC., E. parkeriana DC., E. tefeensis O. Berg, E. vellozii O. Berg., stenocalyx patrisii (Vahl) O. Berg), and Eugenia polystachya Rich. (syn. E. forsteri O. Berg, E. schlechtendaliana O. Berg) [4] are shrubs or small trees of 2-5 m, with a wide occurrence in the Brazilian Amazon.

The Myrtaceae family is known for the high terpene concentration of the foliage and the considerable qualitative and quantitative variation in foliar terpenes at taxonomic, population, and individual levels [5,6]. Many Eugenia species are appreciated for their edible fruits, such as E. uniflora L. (pitanga), E. involucrata DC. (cereja-do-mato), E. jambolana Lam. (jamelão), E. pyriformis Cambess. (uvaia), and E. dysenterica DC. (cagaita). Beyond the volatiles of the fruits, these species also accumulate essential oils in their leaves [7-11]. Sesquiterpene hydrocarbons and oxygenated sesquiterpenes predominate in the essential oils of Eugenia and they are from the germacrane, caryophylane, and guaiane types [12,13].

Essential oils of Eugenia have significant biological activities, such as anticonvulsant [14], antibacterial [15], antifungal [16], antiparasitic [17], and insecticidal [18] activities. Additionally, some Eugenia oils have been reported as antioxidant and cytotoxic. The oil of Eugenia caryophyllata (clove) (syn. Syzygium aromaticum (L.) Merril \& Perry) is rich in eugenol and is a powerful natural antioxidant, with different mechanisms of action, such as radical scavenging, metals chelation, and the inhibition of lipid peroxidation [19]. Furthermore, clove oil showed cytotoxic activity and the induction of apoptosis in human promyelocytic leukemia cells (HL-60) [20].

The aim of the present study was to analyze the composition of the oils of Eugenia egensis, E. flavescens, E. patrisii, and E. polystachya, and evaluate their cytotoxic and antioxidant properties.

\section{Materials and Methods}

\subsection{Plant Material}

Botanical material (aerial parts, $500 \mathrm{~g}$ each plant) was collected in three municipalities located in the Southeast Pará state, Brazil, during the rainy season (January 2011). Eugenia egensis DC. (MG 181220) was collected in the city of Marabá. Eugenia flavescens DC. (MG 200127) and E. polystachya Rich. (MG191868) were sampled in the Carajás National Forest, in the town of Parauapebas. Eugenia patrisii Vahl. (MG 200132) was collected in the city of São Geraldo do Araguaia. Eugenia species vouchers were deposited in the Herbarium of Emilio Goeldi Museum (MG), the city of Belém, Pará state, Brazil.

\subsection{Plant Processing and Extraction of the Essentials Oils}

Aerial parts (leaves and thin stems) of the plants were air-dried, grinded, and submitted to hydrodistillation using Clevenger-type apparatus (100 g, $3 \mathrm{~h}$ ). The oils were dried over anhydrous sodium sulfate, and their percentage contents were calculated by the plant dry weight. The moisture contents of the samples were computed after phase separation using a Dean-Stark trap (5 g, $60 \mathrm{~min}$ ) and toluene as the solvent phase.

\subsection{Oil Composition Analysis}

Analyses of the oils were carried out on a GC-MS Thermo-Electron model Focus DSQ II (Thermo Fisher Scientific, Waltham, MA, USA), under the following conditions: DB-5ms (30 $\mathrm{m} \times 0.25 \mathrm{~mm}$; $0.25 \mathrm{~mm}$ film thickness) fused-silica capillary column (Agilent J\&W GC Columns, Santa Clara, CA, USA); programmed temperature, $60-240{ }^{\circ} \mathrm{C}\left(3{ }^{\circ} \mathrm{C} / \mathrm{min}\right)$; injector temperature, $250{ }^{\circ} \mathrm{C}$; carrier gas, helium, adjusted to a linear velocity of $32 \mathrm{~cm} / \mathrm{s}$ (measured at $100{ }^{\circ} \mathrm{C}$ ); injection type, split $(1.0 \mu \mathrm{L})$, from 1:1000 hexane solution; split flow was adjusted to yield a 20:1 ratio; septum sweep was a constant $10 \mathrm{~mL} / \mathrm{min}$; EIMS, electron energy, $70 \mathrm{eV}$; temperature of the ion source and connection parts, $200^{\circ} \mathrm{C}$. The quantitative data regarding the volatile constituents were obtained by peak area 
normalization using a FOCUS GC/FID (Thermo Fisher Scientific, Waltham, MA, USA) operated under similar conditions for the GC-MS, except the carrier gas, which was nitrogen. The retention index was calculated for all the volatile constituents using a homologous series of $n$-alkanes $\left(C_{8}-C_{32}\right.$, Sigma-Aldrich, St. Louis, MO, USA), according to Van den Dool and Kratz (1963) [21].

\subsection{Antioxidant Assay}

The antioxidant activity of the Eugenia oils was determined by the DPPH radical scavenging assay. DPPH is a stable dark violet free radical with a maximum absorption at $517 \mathrm{~nm}$, which is reduced in the presence of antioxidants. Each sample $(5 \mu \mathrm{L})$ was mixed with Tris- $\mathrm{HCl}$ buffer $(100 \mathrm{mM}$, $900 \mu \mathrm{L}, \mathrm{pH} 7.4)$, ethanol $(40 \mu \mathrm{L})$, and Tween 20 solution $(0.5 \%, 50 \mu \mathrm{L}, w / w)$, and was then added to DPPH $(0.5 \mathrm{mM}, 1 \mathrm{~mL})$ in ethanol. The standard curves were prepared using Trolox and BHA (1.0 to $8.0 \mu \mathrm{g} / \mathrm{mL}$ ), which are standards of hydrosoluble and liposoluble antioxidants, respectively. The results were expressed as milligrams of Trolox $(\mathrm{mgTE} / \mathrm{mL})$ and BHA $(\mathrm{mg}$ BHAE $/ \mathrm{mL})$ equivalents per milliliter of the sample [22].

\subsection{Cytotoxicity Assay (Against Cancer Cell Lines)}

The MTT colorimetric assay was used to measure the cell metabolic activity [23]. The oils ( 0.2 to $25 \mu \mathrm{g} / \mathrm{mL}$ ) were tested for cytotoxic activity against three cancer cell lines: HCT-116 (colon), SKMEL19 (melanoma), AGP-01 (gastric). All cell lines were maintained in DMEM (Dulbecco's Modified Eagle Medium) medium supplemented with fetal bovine serum $(10 \%)$, glutamine $(2 \mathrm{mM})$, penicillin $(100 \mathrm{U} / \mathrm{mL})$, streptomycin $(100 \mu \mathrm{g} / \mathrm{mL})$ at $37{ }^{\circ} \mathrm{C}$ with $5 \% \mathrm{CO}_{2}$. Each oil was dissolved in DMSO to obtain a concentration of $10 \mathrm{mg} / \mathrm{mL}$. The final concentration of DMSO in the culture medium was kept constant, below $0.1 \%(v / v)$. Essential oils $(25 \mu \mathrm{g})$ were incubated with the cells for $72 \mathrm{~h}$. The negative control received the same amount of DMSO $(0.001 \%$ in the highest concentration). The cell viability was determined by reduction of the yellow dye 3-(4,5-dimethyl-2-thiazol)-2,5-diphenyl-2H-tetrazolium bromide (MTT) to a blue formazan product. Doxorubicin and eugenol were the positive controls.

\subsection{Cell Membrane Disruption}

The potential of the cell membrane lyses was evaluated by the release of the hemoglobin in the medium. The test was performed in 96-well plates using mouse hemoglobin suspension ( $2 \%)$ in $\mathrm{NaCl}$ solution $(0.85 \%)$, containing $\mathrm{CaCl}_{2}(10 \mathrm{mM})$. The oils, diluted as mentioned above, were tested at $200 \mu \mathrm{g} / \mathrm{mL}$. After incubation at room temperature for $1 \mathrm{~h}$, followed by centrifugation, the supernatant was removed, and the liberated hemoglobin was measured spectrophotometrically at $540 \mathrm{~nm}$. DMSO was used as the negative control and Triton X-100 (1\%) was employed as the positive control [24].

\subsection{Statistical Analysis}

Samples were assayed in triplicate, and the results are shown as means \pm standard deviation. Analysis of variance was conducted, and the differences between variables were tested for significance by a Tukey test. Differences at $p<0.05$ were considered statistically significant. The $I C_{50}$ 's values were calculated by nonlinear regression using the GraphPad program (version 5.0, Intuitive Software for Science, San Diego, CA, USA).

\section{Results and Discussion}

\subsection{Essential Oil Composition}

The dried leaves and fine stems (aerial parts) of Eugenia egensis, E. flavescens, E. patrisii, and E. polystachya provided oil yields of $2.5 \%, 1.0 \%, 0.7 \%$, and $1.0 \%$, respectively. Individual components were identified by comparison of both mass spectrum and GC retention data with authentic compounds, previously analyzed and stored in the data system. Furthermore, they were identified with the aid of commercial libraries containing the retention indices and mass 
spectra of volatile compounds, commonly found in essential oils $[25,26]$. One hundred volatile compounds were identified, corresponding to an average of $93 \%$ of the total composition of the oils (Table 1). Sesquiterpenes were the most highly represented class, as many hydrocarbons and oxygenated constituents.

Table 1. Composition (\%) of the oils of Eugenia species.

\begin{tabular}{|c|c|c|c|c|c|c|}
\hline Constituents & $\mathbf{R I}_{\text {Calc. }}$ & $\mathbf{R I}_{\text {Lit. }}$ & $\begin{array}{l}\text { Eugenia } \\
\text { egensis }\end{array}$ & $\begin{array}{c}\text { Eugenia } \\
\text { flavescens }\end{array}$ & $\begin{array}{l}\text { Eugenia } \\
\text { patrisii }\end{array}$ & $\begin{array}{c}\text { Eugenia } \\
\text { polystachya }\end{array}$ \\
\hline Limonene & 1026 & 1024 & & & & 0.1 \\
\hline$\alpha$-Terpineol & 1187 & 1186 & & & 0.1 & \\
\hline Thymol & 1290 & 1289 & & & 0.1 & \\
\hline$\delta$-Elemene & 1337 & 1335 & 1.6 & 0.5 & 0.3 & 4.1 \\
\hline$\alpha$-Cubebene & 1348 & 1345 & 2.2 & & & 0.1 \\
\hline$\alpha$-Ylangene & 1374 & 1373 & 0.1 & & & 0.1 \\
\hline$\alpha$-Copaene & 1376 & 1374 & 1.6 & & 0.1 & 0.6 \\
\hline$\beta$-Bourbonene & 1388 & 1387 & 0.2 & & & 0.3 \\
\hline$\beta$-Elemene & 1390 & 1389 & 2.5 & 0.2 & 0.1 & 2.2 \\
\hline 7-epi-Sesquithujene & 1392 & 1390 & & 0.1 & & \\
\hline Sesquithujene & 1407 & 1405 & & 0.1 & & \\
\hline$\alpha$-Gurjunene & 1410 & 1409 & 1.5 & & & \\
\hline$(Z)-\alpha$-Bergamotene & 1412 & 1411 & & 0.2 & & \\
\hline$\beta$-Caryophyllene & 1418 & 1417 & 8.9 & 2.8 & 0.9 & 2.3 \\
\hline$\beta$-Ylangene & 1420 & 1419 & & & & 5.0 \\
\hline$\beta$-Gurjunene & 1432 & 1431 & 0.7 & 0.2 & 0.1 & 3.5 \\
\hline (E)- $\alpha$-Bergamotene & 1433 & 1432 & & 0.4 & & \\
\hline$\alpha$-Guaiene & 1439 & 1437 & 0.1 & & & 0.2 \\
\hline Aromadendrene & 1440 & 1439 & 0.1 & & 0.1 & \\
\hline (Z)- $\beta$-Farnesene & 1442 & 1440 & & 0.4 & & \\
\hline 6,9-Guaiadiene & 1444 & 1442 & & & & 1.2 \\
\hline (E)-Muurola-3,5-diene & 1454 & 1451 & 5.9 & & & \\
\hline$\alpha$-Humulene & 1455 & 1452 & 2.0 & & 0.4 & 1.3 \\
\hline Geranyl acetone & 1456 & 1453 & & & 0.6 & \\
\hline (E)- $\beta$-Farnesene & 1457 & 1454 & & 4.7 & & \\
\hline$\beta$-Santalene & 1460 & 1457 & & 0.1 & & \\
\hline allo-Aromadendrene & 1462 & 1458 & 0.9 & & 0.2 & \\
\hline (Z)-Cadina-1(6),4-diene & 1464 & 1461 & 0.1 & & & 0.6 \\
\hline Ishwarane & 1467 & 1465 & & & & 15.7 \\
\hline$\beta$-Acoradiene & 1470 & 1469 & & 0.2 & & \\
\hline Dauca-5,8-diene & 1473 & 1471 & & 1.2 & & \\
\hline (E)-Cadina-1(6),4-diene & 1476 & 1475 & 1.6 & & & \\
\hline$\gamma$-Gurjunene & 1477 & 1475 & & & & 0.7 \\
\hline$\gamma$-Muurolene & 1480 & 1478 & 0.3 & & 0.1 & 1.0 \\
\hline Germacrene D & 1486 & 1484 & 2.2 & & 0.8 & 18.4 \\
\hline Aristolochene & 1488 & 1487 & & & & 2.1 \\
\hline$\beta$-Selinene & 1490 & 1489 & 0.4 & & 0.1 & 0.9 \\
\hline (Z)- $\beta$-Guaiene & 1494 & 1492 & 3.8 & & & 1.4 \\
\hline$\alpha$-Zingiberene & 1496 & 1493 & & 1.6 & & \\
\hline Viridiflorene & 1497 & 1496 & & & 0.3 & \\
\hline Bicyclogermacrene & 1501 & 1500 & 1.2 & & 0.5 & 5.1 \\
\hline$\alpha$-Muurolene & 1502 & 1500 & 0.5 & & 0.2 & 1.7 \\
\hline$\beta$-Bisabolene & 1506 & 1505 & & 34.7 & 0.3 & \\
\hline (Z)- $\alpha$-Bisabolene & 1508 & 1506 & & 0.4 & & \\
\hline$\delta$-Amorphene & 1512 & 1511 & & 0.3 & & \\
\hline$\gamma$-Cadinene & 1515 & 1513 & 0.2 & & 0.1 & 0.8 \\
\hline Cubebol & 1516 & 1514 & 0.1 & & 0.1 & 0.5 \\
\hline 7-epi- $\alpha$-Selinene & 1521 & 1520 & & & & 7.5 \\
\hline$\beta$-Sesquiphellandrene & 1523 & 1521 & & 3.4 & 0.1 & \\
\hline (E)-Calamenene & 1523 & 1521 & 6.1 & & 0.1 & 0.3 \\
\hline$\delta$-Cadinene & 1524 & 1522 & 2.3 & & 0.6 & \\
\hline (E)-iso- $\gamma$-Bisabolene & 1530 & 1529 & & 5.1 & & \\
\hline$(E)-\gamma$-Bisabolene & 1531 & 1530 & & 35.0 & & \\
\hline (E)-Cadina-1,4-diene & 1534 & 1533 & 6.3 & & & 0.2 \\
\hline 10-epi-Cubebol & 1535 & 1533 & & & & 0.1 \\
\hline$\alpha$-Cadinene & 1539 & 1537 & & & 0.1 & 0.2 \\
\hline
\end{tabular}


Table 1. Cont

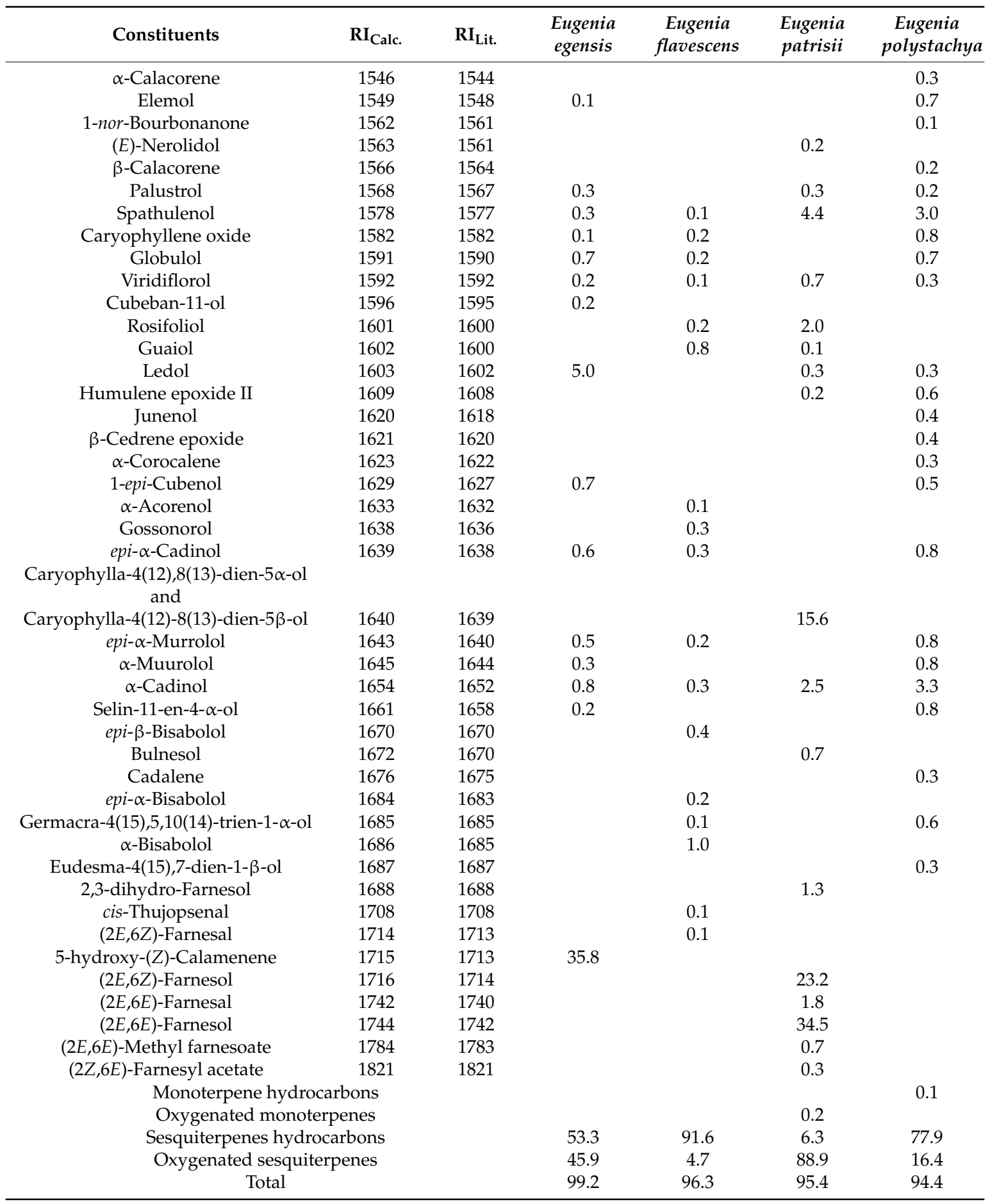

$\mathrm{RI}_{\mathrm{Calc}}=$ based on DB-5ms capillary column and alkane standards $\left(\mathrm{C}_{8}-\mathrm{C}_{32}\right)$ according Van den Dool and Kratz (1963). $\mathrm{RI}_{\text {Lit. }}=$ based on Adams (2007).

The principal constituents (above 5\%) of E. egensis oil were 5-hydroxy-cis-calemenene (35.8\%), $\beta$-caryophyllene $(8.9 \%)$, trans-cadina-1,4-diene $(6.3 \%)$, trans-calamenene $(6.1 \%)$, trans-muurola-3, 5-diene $(5.9 \%)$, and ledol $(5.0 \%)$. These sesquiterpenes were grouped in accordance with the following biosynthetical pathways: cadinane, muurolane, and caryophyllane. Eugenia polystachya oil was dominated by germacrene D (18.4\%), ishwarane $(15.7 \%)$, 7-epi- $\alpha$-selinene $(7.5 \%)$, and bicyclogermacrene $(5.1 \%)$. Therefore, sesquiterpenes presented the germacrane and selinane 
structural-types. To our knowledge, it is the first study on the composition of the E. egensis and E. polystachya oils, and the first report on the occurrence of 5-hydroxy-cis-calemenene as a significant constituent in Eugenia essential oils. Other sesquiterpenes with a germacrane skeleton have been reported in E. protenta [27] and E. uniflora [28].

Eugenia flavescens oil is rich in (E)- $\gamma$-bisabolene (35.0\%), $\beta$-bisabolene $(34.7 \%)$, and $(E)$-iso- $\gamma$ -bisabolene (5.1\%), comprising about $75.0 \%$ of the total oil composition. A previous study reported the occurrence of germacrene D and bicyclogermacrene in the oil of a specimen of E. flavescens collected in the city of Maracanã, Pará State, Brazil [29]. A notable occurrence of the bisabolane skeleton was described in other Myrtaceae species. $\alpha$-Bisabolene occurs in the oils of Myrcia splendens [13], M. fallax and M. glabra [30], M. obtecta [31], M. laruotteana [32], and M. bracteata [33]. The oxygenated sesquiterpenes (2E,6E)-farnesol (34.5\%), (2E,6Z)-farnesol $(23.2 \%)$, and the mixture of caryophylla-4(12),8(13)-dien-5 $\alpha$-ol and caryophylla-4(12),8(13)-dien-5 $\beta$-ol (15.6\%) were the main constituents of the oil of Eugenia patrissii. Therefore, sesquiterpene compounds belong to the caryophyllane and acyclic groups. Another sample of E. flavescens, collected in the city of Maracanã, Pará State, Brazil, different to the sample studied in this paper, showed the hydrocarbon sesquiterpenes trans-cadina-1,4-diene, trans-muurola-3,5-diene, and $\beta$-caryophyllene, as the primary components [29].

The difference found in the main constituents of the oils of E. flavescens and E. patrissii, when comparing them separately with the previously described oils [29], is due to the presence of two distinct chemotypes, whose specimens were sampled at different collection sites; the first in a secondary forest area in the northeast of Pará and the second in an area of savanna in the south of Pará, Brazil, with a very diverse soil and climate environment, and a distance between them of about $1000 \mathrm{~km}$.

\subsection{Antioxidant Activity}

The radical scavenging activity using the DPPH radical (2,2-diphenyl-1-picrylhydrazyl) was tested with the different Eugenia oils, and the absorbance at $517 \mathrm{~nm}$ was observed. Regarding percentage values, the inhibiting activity (over $120 \mathrm{~min}$ ) was calculated in the following order: E. egensis $(79.6 \pm 4.3 \%)$, E. flavescens $(45.1 \pm 2.5 \%)$, E. patrisii $(40.9 \pm 4.6 \%)$, and E. polystachya $(11.5 \pm 1.3 \%)$. The antioxidant activity was expressed in comparison with the Trolox and BHA standards (Figure 1).
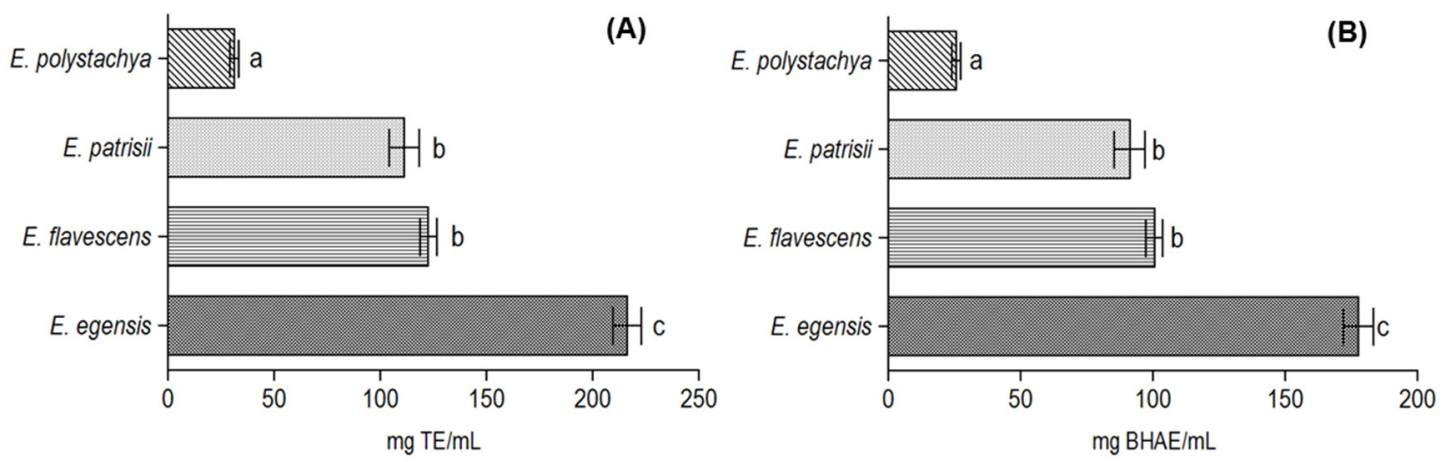

Figure 1. Antioxidant activity of the Eugenia oils by the DPPH assay. Results expressed in milligrams of Trolox (A) and BHA (B) equivalent per milliliter of sample. Mean \pm standard deviation $(n=3)$. Values with different letters in the figure represents statistical differences at the $p<0.05$ level (Tukey's test).

The highest activity observed for the E. egensis oil (TEAC $=216.5 \pm 11.6 \mathrm{mg} \mathrm{TE} / \mathrm{mL}$ and $177.6 \pm 9.8 \mathrm{mg} \mathrm{BHAE} / \mathrm{mL}$ ) could be attributed to the oxygenated sesquiterpene 5-hydroxy-cis-calamenene. The presence of a phenolic ring in the structure of 5-hydroxy-cis-calamenene enhances the antioxidant activity due to its ability for scavenging free radicals, the donation of hydrogen atoms or electrons, or chelation with metal cations [34]. The oil of Croton cajucara Benth. that contains $33.0 \%$ of the isomer 7-hydroxy-calamenene, showed significant antioxidant activity in the DDPH assay and its $I C_{50}$ value was $35.6 \mu \mathrm{g} / \mathrm{mL}$, only four times less active than rutin $\left(I C_{50}\right.$ 
$9.3 \mu \mathrm{g} / \mathrm{mL}$ ) [35]. Additionally, it was reported that the isomer 8-hydroxy-calamenene could attenuate the retinal damage significantly, a common risk factor for glaucoma disease caused by oxidative stress, exhibiting neuroprotective effects when tested in vitro and in vivo [36].

Eugenia flavescens $(122.6 \pm 6.8 \mathrm{mg} \mathrm{TE} / \mathrm{mL}$ and $100.6 \pm 5.4 \mathrm{mg} \mathrm{BHAE} / \mathrm{mL})$ and E. patrisii $(111.2 \pm 12.4 \mathrm{mg} \mathrm{TE} / \mathrm{mL}$ and $91.3 \pm 10.1 \mathrm{~m} \mathrm{BHAE} / \mathrm{mL})$ oils showed moderate antioxidant activity. The main constituents of these two oils are sesquiterpene hydrocarbons with bisabolane and farnesane type structures, respectively (see Table 1). The oil of Psammogeton canescens Vatke, rich in $\beta$-bisabolene (33.4\%), showing significant antioxidant activity in the DPPH assay, was previously reported and strengthens our results [37]. On the other hand, to the present date, no information has been reported on the antioxidant activity of the farnesol isomers.

\subsection{Cytotoxic Activity}

Among many valuable plant products, the essential oils are used in complementary medical treatment strategies. The action of essential oils and their constituents has been studied for a variety of cancer types [38]. In the present study, the antiproliferative effect of different Eugenia oils was tested against three human cancer cell lines (AGP-01, HCT-116, and SKMEL-19) and one normal human fibroblast cell line (MRC-5), using the MTT assay. The $I C_{50}$ values were determined after $72 \mathrm{~h}$ exposure, as shown in Table 2. Eugenia flavescens, E. patrisii, and E. polystachya oils presented cytotoxicity against the HCT-116 colon cancer cell line, except for the oil of E. egensis, which did not display cytotoxicity against any of the cells until the concentration of $25 \mu \mathrm{g} / \mathrm{mL}$. The oil of E. polystachya was the most active, with an $I C_{50}$ value of $10.3 \mu \mathrm{g} / \mathrm{mL}$. Germacrene D was the main constituent of this oil $(18.4 \%)$ and, previously, it was identified with a significant percentage in the oils of Guatteria diospyroides, G. oliviformis, and Unonopsis costaricensis. These Annonaceae oils showed remarkable cytotoxic activities against MDA-MB-231 cells (human breast tumor) [39]. The germacrane group was also highlighted in the study of the essential oil of Porcelia macrocarpa, another Annonaceae species. A mixture of germacrene $\mathrm{D}$ and bicyclogermacrene isolated from its oil showed significant cytotoxic potential against HL-60 cells (human leukemia) [40]. As mentioned before, the oil of Eugenia caryophyllata (clove) exhibits strong cytotoxic activity in HL-60 cells [20], as well as being active against colon and melanoma cancer cells [41,42]. Thus, the results in Table 2 were compared to eugenol, the major constituent of clove oil. Interestingly, the oil of E. polystachya exhibits no activity against the normal MRC-5 fibroblast cell line, whereas the other two oils from E. flavescens and E. patrisii display the same range of cytotoxicity on HCT-116 cancer cells and in MCR-5 normal cells, what makes them suitable for further investigation. To our knowledge, this is the first time that the cytotoxic activity of these oils has been reported. All tested oils did not display lytic activity against red blood cells (see Table 2).

Table 2. Cytotoxic activity of the Eugenia oils on cell lines, after $72 \mathrm{~h}$ exposure.

\begin{tabular}{|c|c|c|c|c|c|}
\hline \multirow{3}{*}{$\begin{array}{l}\text { Eugenia } \\
\text { Species }\end{array}$} & \multicolumn{4}{|c|}{$I C_{50}(\mu \mathrm{g} / \mathrm{mL}) *$} & \multirow{2}{*}{$\begin{array}{c}\text { Hemolysis } \\
(\mu \mathrm{g} / \mathrm{mL})\end{array}$} \\
\hline & AGP-01 & HCT-116 & SKMEL19 & MRC5 & \\
\hline & (Gastric) & (Colon) & (Melanoma) & (Human Fibroblast) & \\
\hline E. egensis & $>25$ & $>25$ & $>25$ & ND & $>200$ \\
\hline E. flavescens & $>25$ & $13.9^{\mathrm{a}}(12.0-15.9)$ & $>25$ & $14.0^{\mathrm{a}}(10.4-18.6)$ & $>200$ \\
\hline E. patrisii & $>25$ & $16.4^{\mathrm{b}}(14.6-18.3)$ & $>25$ & $18.1^{\mathrm{b}}(13.9-23.4)$ & $>200$ \\
\hline E. polystachya & $>25$ & $10.3^{\mathrm{c}}(8.3-12.8)$ & $>25$ & $>25$ & $>200$ \\
\hline \multirow{2}{*}{ Doxorubicin } & $0.254 \mu \mathrm{M}$ & $0.10 \mu \mathrm{M}^{\mathrm{d}}$ & $0.045 \mu \mathrm{M}$ & $0.20 \mu \mathrm{M}(0.16-0.25)$ & $>200 \mu \mathrm{M}$ \\
\hline & & HCT-15/HT-29 & Sbc-12/WM3211 & & \\
\hline Eugenol & & $500.0 \mu \mathrm{M} / 300 \mu \mathrm{M}$ & $0.5 \mu \mathrm{M}$ & & \\
\hline
\end{tabular}


Antioxidants are believed to be directly antimutagenic [43] and anticarcinogenic due to their radical scavenging properties $[44,45]$. The oil of E. egensis showed significant antioxidant activity, but no cytotoxicity against cancer cell lines $\left(I C_{50}>25.0 \mu \mathrm{g} / \mathrm{mL}\right)$. These results should be attributed to the presence of the phenolic ring in the structure of 5-hydroxy-cis-calamenene, as many phenolic compounds are reported as cytoprotectives [46].

\section{Conclusions}

Our investigation of the chemical profile of the Eugenia essential oils has contributed to chemosystematic studies of Myrtaceae species, for which the occurrence of bisabolane-type skeletons and acyclic sesquiterpenes as important characteristics have been reported. Additionally, it is the first report for the presence of 5-hydroxy-cis-calamenene in Eugenia oils. The essential oils showed significant antioxidant activity and selective cytotoxicity against HCT-116 cancer cells (colon) and did not promote membrane damage. The results suggest that Eugenia oils could be tested in future studies for the treatment of colon cancer and oxidative stress management.

Acknowledgments: The authors are grateful to Conselho Nacional de Desenvolvimento Científico e Tecnológico (CNPq) and Coordenação de Aperfeiçoamento de Pessoal de Nível Superior (CAPES) and Fundação Amazônia de Amparo a Estudos e Pesquisas (FAPESPA) for their financial support.

Author Contributions: J.K.R.d.S. and J.G.S.M. conducted the research design; E.H.A.A. completed the botanical species identification; J.K.R.d.S., L.H.B., N.C.F.d.S., A.F.R., and R.C.M. contributed to laboratory research conduction; J.K.R.d.S., E.H.A.A., R.C.M., and J.G.S.M. analyzed the data and prepared the manuscript. All authors read and approved the final manuscript.

Conflicts of Interest: The authors declare no conflict of interest.

\section{Abbreviations}

The following abbreviations are used in this manuscript.

DMSO dimethylsulfoxide

2,2-diphenyl-1-picrylhydrazyl

GC-MS gas chromatography/mass spectrometry

GC-FID gas chromatography/flame ionization detector

MTT 3-(4,5-dimethylthiazol-2-yl)-2,5-diphenyl tetrazolium bromide

TEAC trolox equivalent antioxidant capacity

Triton X-100 nonionic surfactant, octylphenol ethoxylate

\section{References}

1. Wilson, P.G.; O’Brien, M.M.; Gadek, P.A.; Quinn, C.J. Myrtaceae revisited: A reassessment of intrafamilial groups. Am. J. Bot. 2001, 88, 2013-2025. [CrossRef] [PubMed]

2. Landrum, L.R.; Kawasaki, M.L. The genera of Myrtaceae in Brazil: An illustrated synoptic treatment and identification keys. Brittonia 1977, 49, 508-536. [CrossRef]

3. Sobral, M.; Proença, C.; Souza, M.; Mazine, F.; Lucas, E. Myrtaceae: Lista de Espécies da Flora do Brazil; Jardim Botânico do Rio de Janeiro: Rio de Janeiro, Brazil, 2010. Available online: http: / floradobrasil.jbrj.gov.br/ reflora/floradobrasil/FB171 (accessed on 15 May 2016).

4. Missouri Botanical Garden. 2016. Available online: http://www.tropicos.org (accessed on 11 November 2016).

5. Keszei, A.; Brubaker, C.L.; Foley, W.J. A molecular perspective on terpene formation in Australian Myrtaceae. Aust. J. Bot. 2008, 56, 197-213. [CrossRef]

6. Padovan, M.; Keszei, A.; Külheim, C.; Foley, W.J. The evolution of foliar terpene diversity in Myrtaceae. Phytochem. Rev. 2014, 13, 695-716. [CrossRef]

7. Costa, D.P.; Santos, S.C.; Seraphin, J.C.; Ferri, P.H. Seasonal variability of essential oils of Eugenia uniflora leaves. J. Braz. Chem. Soc. 2009, 20, 1287-1293. [CrossRef] 
8. Henriques, A.T.; Sobral, M.E.; Cauduro, A.D.; Schapoval, E.E.S.; Bassani, V.L.; Lamaty, G.; Menut, C.; Bessière, J.M. Aromatic plants from Brazil. II. The chemical composition of some Eugenia essential oils. J. Essent. Oil Res. 1993, 5, 501-505. [CrossRef]

9. Craveiro, A.A.; Andrade, C.H.S.; Matos, F.J.A.; Alencar, J.W.; Machado, M.I.L. Essential oil of Eugenia jambolana. J. Nat. Prod. 1983, 46, 591-592. [CrossRef]

10. Apel, M.A.; Sobral, M.E.; Schapoval, E.E.S.; Henriques, A.T.; Menut, C.; Bessiére, J.M. Chemical composition of the essential oils of E. beaurepaireana and E. pyriformis: Section Dichotomae. J. Essent. Oil Res. 2004, 16, 191-192. [CrossRef]

11. Feitosa, C.M.; Barbosa, A.R.; de Melo, C.H.S.; Freitas, R.M.; Fontes, J.E.N.; Costa, E.V.; Rashed, K.N.Z.; da Costa Junior, J.S. Antioxidant and anticholinesterase activities of the essential oil of Eugenia dysenterica DC. Afr. J. Pharm. Pharmacol. 2017, 11, 241-249.

12. Siani, A.C.; Azevedo, M.B.M.; Ramos, M.F.S.; Trigo, J.R. Monoterpenes and sesquiterpenes of Neotropical Myrtaceae. In Current Trends in Phytochemistry; Research Signpost: Trivandrum, India, 2008; pp. $223-251$.

13. Nakamura, M.J.; Monteiro, S.S.; Bizarri, C.H.B.; Siani, A.C.; Ramos, M.F.S. Essential oils of four Myrtaceae species from the Brazilian Southeast. Biochem. Syst. Ecol. 2010, 38, 1170-1175. [CrossRef]

14. Pourgholami, M.H.; Kamalinejad, M.; Javadi, M.; Majzoob, S.; Sayyah, M. Evaluation of the anticonvulsant activity of the essential oil of Eugenia caryophyllata in male mice. J. Ethnopharmacol. 1999, 64, 167-171. [CrossRef]

15. Ogunwande, I.A.; Olawore, N.O.; Ekundayo, O.; Walker, T.M.; Schmidt, J.M.; Setzer, W.N. Studies on the essential oils composition, antibacterial and cytotoxicity of Eugenia uniflora L. Int. J. Aromather. 2005, 15, 147-152. [CrossRef]

16. Lee, Y.-S.; Kim, J.; Shin, S.-C.; Lee, S.-G.; Park, I.-K. Antifungal activity of Myrtaceae essential oils and their components against three phytopathogenic fungi. Flav. Fragr. J. 2008, 23, 23-28. [CrossRef]

17. Santos, K.K.A.; Matias, E.F.F.; Tintino, S.R.; Souza, C.E.S.; Braga, M.F.B.M.; Guedes, G.M.M.; Rolón, M.; Veja, C.; de Arias, A.R.; Costa, J.G.M.; et al. Anti-Trypanosoma cruzi and cytotoxic activities of Eugenia uniflora L. Exp. Parasitol. 2012, 131, 130-132. [CrossRef] [PubMed]

18. Gonzalez, M.S.; Lima, B.G.; Oliveira, A.F.R.; Nunes, D.D.; Fernandes, C.P.; Santos, M.G.; Tietbohl, L.A.C.; Mello, C.B.; Rocha, L.; Federa, D. Effects of essential oil from leaves of Eugenia sulcata on the development of agricultural pest insects. Rev. Bras. Farmacogn. 2014, 24, 413-418. [CrossRef]

19. Gülçin, I.; Elmastas, M.; Aboul-Enein, H.Y. Antioxidant activity of clove oil—A powerful antioxidant source. Arab. J. Chem. 2012, 5, 489-499. [CrossRef]

20. Yoo, C.-B.; Hana, K.-T.; Cho, K.-S.; Hab, J.; Park, H.-J.; Nam, J.-H.; Kil, U.-H.; Lee, K.-T. Eugenol isolated from the essential oil of Eugenia caryophyllata induces a reactive oxygen species-mediated apoptosis in HL-60 human promyelocytic leukemia cells. Cancer Lett. 2005, 225, 41-52. [CrossRef] [PubMed]

21. Van den Dool, H.; Kratz, P.D.J.A. Generalization of the retention index system including linear temperature programmed gas-liquid partition chromatography. J. Chromatogr. A 1963, 11, 463-471. [CrossRef]

22. Choi, H.-S.; Song, H.S.; Ukeda, H.; Sawamura, M. Radical-scavenging activities of Citrus essential oils and their components: Detection using 1,1-diphenyl-2-picrylhydrazyl. J. Agric. Food Chem. 2000, 48, 4156-4161. [CrossRef] [PubMed]

23. Mosmann, T. Rapid colorimetric assay for cellular growth and survival: Application to proliferation and cytotoxicity assays. J. Immunol. Methods 1983, 65, 55-63. [CrossRef]

24. Oliveira, A.C.; Hillard, E.A.; Pigeon, P.; Rocha, D.D.; Rodrigues, F.A.R.; Montenegro, R.C.; Costa-Lotufo, L.V.; Goulart, M.O.F.; Jaouen, G. Biological evaluation of twenty-eight ferrocenyltetrasubstitued olefins: Cancer cell growth inhibition, ROS production and hemolytic activity. Eur. J. Med. Chem. 2011, 46, 3778-3787. [CrossRef] [PubMed]

25. NIST-National Institute of Standards and Technology. Mass Spectral Library (NIST/EPA/NIH, v. 2.0d); The NIST Mass Spectrometry Data Center: Gaithersburg, MD, USA, 2005.

26. Adams, R.P. Identification of Essential Oil Components by Gas Chromatography/Mass Spectrometry, 4th ed.; Allured Publishing Corporation: Carol Stream, IL, USA, 2007.

27. Zoghbi, M.G.B.; Guilhon, G.M.S.P.; Sarges, F.N.; Pereira, R.A.; Oliveira, J. Chemical variability of the volatiles from the leaves of Eugenia protenta McVaugh (Myrtaceae) growing wild in the North of Brazil. Biochem. Syst. Ecol. 2011, 9, 660-665. [CrossRef] 
28. Victoria, F.N.; Lenardão, E.J.L.; Perin, G.; Jacob, R.G.; Alves, D.; da Silva, W.P.; da Motta, A.S.; Nascente, O.S. Essential oil of the leaves of Eugenia uniflora L.: Antioxidant and antimicrobial properties. Food Chem. Toxicol. 2012, 50, 2668-2674. [CrossRef] [PubMed]

29. Pereira, R.A.; Zoghbi, M.G.B.; Bastos, M.N.C. Essential oils of twelve species of Myrtaceae growing wild in the sandbank of the Resex Maracanã, State of Pará, Brazil. J. Essent. Oil Bear. Plants 2010, 13, 440-450. [CrossRef]

30. Henriques, A.T.; Sobral, M.; Bridi, R.; Vérin, P.; Menut, C.; Lamaty, G.; Bessière, J.M. Essential oil from five southern Brazilian species of Myrcia (Myrtaceae). J. Essent. Oil Res. 1997, 9, 13-18. [CrossRef]

31. Limberger, R.P.; Sobral, M.; Henriques, A.T. Óleos voláteis de espécies de Myrcia nativas do Rio Grande do Sul. Quim. Nova 2004, 27, 916-919. [CrossRef]

32. Stefanello, M.E.A.; Cervi, A.C.; Wisniewski, A., Jr.; Simionatto, E.L. Essential oil composition of Myrcia laruotteana Camb. J. Essent. Oil Res. 2007, 19, 466-467. [CrossRef]

33. Zoghbi, M.G.B.; Andrade, E.H.A.; da Silva, M.H.L.; Carreira, L.M.M.; Maia, J.G.S. Essential oils from three Myrcia species. Flav. Fragr. J. 2003, 18, 421-424. [CrossRef]

34. Balasundram, N.; Sundram, K.; Samman, S. Phenolic compounds in plants and agri-industrial by-products: Antioxidant activity, occurrence, and potential uses. Food Chem. 2006, 99, 191-203. [CrossRef]

35. Azevedo, M.M.B.; Chaves, F.C.M.; Almeida, C.A.; Bizzo, H.R.; Duarte, R.S.; Campos-Takaki, G.M.; Alviano, C.S.; Alviano, D.S. Antioxidant and antimicrobial activities of 7-hydroxycalamenene-rich essential oils from Croton cajucara Benth. Molecules 2013, 8, 1128-1137. [CrossRef] [PubMed]

36. Jo, H.; Lee, H.J.; Kim, C.Y.; Son, J.-K.; Jung, S. 8-Hydroxycalamenene isolated from the rhizomes of Reynoutria elliptica exerts neuroprotective effects both in vitro and in vivo. Food Chem. Toxicol. 2013, 51, 231-241. [CrossRef] [PubMed]

37. Gholivand, M.B.; Rahimi-Nasrabadi, M.; Batooli, H.; Ebrahimabadi, A.H. Chemical composition and antioxidant activities of the essential oil and methanol extracts of Psammogeton canescens. Food Chem. Toxicol. 2009, 48, 24-28. [CrossRef] [PubMed]

38. Gautam, N.; Mantha, A.K.; Mittal, S. Essential oils and their constituents as anticancer agents: A mechanistic view. BioMed Res. Int. 2014. [CrossRef] [PubMed]

39. Palazzo, M.C.; Wright, H.L.; Agius, B.R.; Wright, B.S.; Moriarity, D.M.; Haber, W.A.; Setzer, W.N. Chemical compositions and biological activities of leaf essential oils of six species of Annonaceae from Monteverde, Costa Rica. Rec. Nat. Prod. 2009, 3, 153-160.

40. Da Silva, E.B.P.; Matsuo, A.L.; Figueiredo, C.R.; Chaves, M.H.; Sartorelli, P.; Lago, J.H.G. Chemical constituents and cytotoxic evaluation of essential oils from leaves of Porcelia macrocarpa (Annonaceae). Nat. Prod. Commun. 2013, 8, 277-279. [PubMed]

41. Jaganathan, S.K.; Mazumdar, A.; Mondhe, D.; Mandal, M. Apoptotic effect of eugenol in human colon cancer cell lines. Cell Biol. Int. 2011, 35, 607-615. [CrossRef] [PubMed]

42. Ghosh, R.; Nadiminty, N.; Fitzpatrick, J.E.; Alworth, W.L.; Slaga, T.J.; Kumar, A.P. Eugenol causes melanoma growth suppression through inhibition of E2F1 transcriptional activity. J. Biol. Chem. 2005, 280, 5812-5819. [CrossRef] [PubMed]

43. Clark, S.F. The biochemistry of antioxidants revisited. Nutr. Clin. Pract. 2002, 17, 5-17. [CrossRef] [PubMed]

44. Ferguson, L.R.; Philpott, M.; Karunasinghe, N. Dietary cancer and prevention using antimutagens. Toxicology 2004, 198, 147-159. [CrossRef] [PubMed]

45. Collins, A.R. Antioxidant intervention as a route to cancer prevention. Eur. J. Cancer 2005, 41, $1923-1930$. [CrossRef] [PubMed]

46. Nayaka, M.A.H.; Sathisha, U.V.; Dharmesh, S.M. Cytoprotective and antioxidant activity of free, conjugated and insoluble-bound phenolic acids from swallow root (Decalepis hamiltonii). Food Chem. 2010, 119, 1307-1312. [CrossRef]

(C) 2017 by the authors. Licensee MDPI, Basel, Switzerland. This article is an open access article distributed under the terms and conditions of the Creative Commons Attribution (CC BY) license (http:/ / creativecommons.org/licenses/by/4.0/). 